\title{
Physics for primary school teachers - some practical experiences
}

\author{
Zdeněk Drozd, Dana Mandíková and Jitka Houfková \\ Department of Physics Education, Faculty of Mathematics and Physics, Charles University, Prague , Czech Republic \\ For correspondence: zdenek.drozd@mff.cuni.cz
}

\begin{abstract}
Physics as a teaching subject starts usually in the sixth year of the school attendance in the Czech Republic. It means that pupils meet physics in the age of eleven or twelve. On the other hand, some basic physics phenomena are included in the primary school teaching subjects. It is mainly school subject "Natural Science" in which the basic knowledge about water, air, electricity, heat, magnetism, optics and others are introduced to little pupils. The above mentioned contradiction represents relevant problem with significant influence on the tuition at the primary school. The authors of this contribution report how they deal with this problem. They developed a new seminar for future primary school teachers. The seminar is still in developing stage, but an important feedback was obtained during last years. There is a very important aspect in the developing of this new university subject, which is reported in present contribution. By this aspect the authors mean the fact, that the seminar was created on request of students themselves. It was great challenge as well as great chance for them to do something for future primary school teachers and offer them a new opportunity how to learn something from physics. The seminar is organized every semester and the authors were obtaining many useful experiences within the tuition of the one. Such a feedback represents a new basis for present modifications of the seminar.
\end{abstract}

Keywords: Primary School Physics, Simple Experiments, Science Education.

\section{Introduction}

The role of science education is very important in primary school education. Small children construct first concepts of the physics phenomena in their minds in this period of life. In present paper we introduce a seminar designed for future primary school teachers, students of Pedagogical Faculty, Charles University, Prague. Primary school teachers are the first ones in the school attendance who introduce pupils to the natural science. It means that they have a crucial role in the building of proper concepts of nature - concepts of physics, chemistry, technology, and so on. On the other hand there are also many opportunities for arising of various misconceptions related to physics and other nature phenomena. Thus it is very important to gain the interest of pupils and to motivate them to future studies. Young pupils are very inquiring, they want to know how things work and they love to do experiments. This was one of the reasons for developing of a new seminar designated for future primary school teachers.

The seminar provides the opportunity to familiarize the future teachers with experiments from the parts of natural science that are taught at primary school and give them an opportunity to try them themselves. The emphasis is put on hands-on activities of the future teachers and on self-production of simple teaching aids, as well as on correct explanations of investigated phenomena and on ways how to present such things to young pupils. The most common misconceptions and their identification form one of the important parts of the seminar. There are many misconceptions in the minds of pre-service teachers too. So, the extermination of such misconceptions is another goal of our seminar.

\section{How it starts?}

There is a very important aspect in the developing of this new type of seminar (by the word "new" we mean the fact, that there is no subject for future primary school teachers similar to this seminar at 
our university). By this aspect the authors mean the fact, that the seminar was created on request of students themselves. It was great challenge as well as great chance for them to do something for future primary school teachers and offer them a new opportunity how to learn something from physics. The seminar has been organized during last seven years and the authors were obtaining many useful experiences within the tuition of the one. Such a feedback represents a new basis for present modifications of the seminar.

\section{Structure of the seminar and its main goal}

The basic seminar (called Experiments in Science at Primary School) takes one semester. There is also advanced seminar in further semester. Both, the basic and advanced seminar, take 135 minutes every week during the semester. This is an example of cooperation between two faculties of Charles University in Prague. The lecturers are from Faculty of Mathematics and Physics and students are from Pedagogical Faculty. Very disconcerting thing is that there is no subject focused on physics in the curricula of future primary school at the Pedagogical Faculty of Charles University in Prague. We can rightfully ask a question, how can these students teach subjects containing physics one day, without proper physics preparation.

As it was mentioned above the seminar consists of ten three-hours experimentally oriented sessions approximately, and every of them is focused on one of basic physics topic. These topics are carefully chosen and almost all aids which are used in the seminar are very simple. All of them can be easily prepared by children during the school lesson immediately. Examples of experiments can be seen from several photos enclosed to the end of this paper. Experiments are frequently discussed with the students from a various frames of reference. Discussion is done in the frame of didactics aspects of the preparation of future primary school teachers in physics and other disciplines which are not a standard part of their professional training.

The topics of the seminar are following: air and its properties, water and its properties, acoustics, heat, light (simple optics), electricity and magnetism (it means electrostatics, electrical circuits, magnets and theirs properties, production of electricity and its transfer between the power station and household), motion and forces, simple machines, Earth and its position in Universe, cosmic flights, weightlessness and some other topics are in the preparation (e.g. energy and physics of human body).

There are lot of simple experiments performed during the seminar sessions. Consequently students with lecturers focus on the explanation of the experiments. Very important question is how to integrate such experiments to the primary school lessons. This is widely discussed during particular individual sessions.

\section{Some examples of the seminar sessions given by photographs}

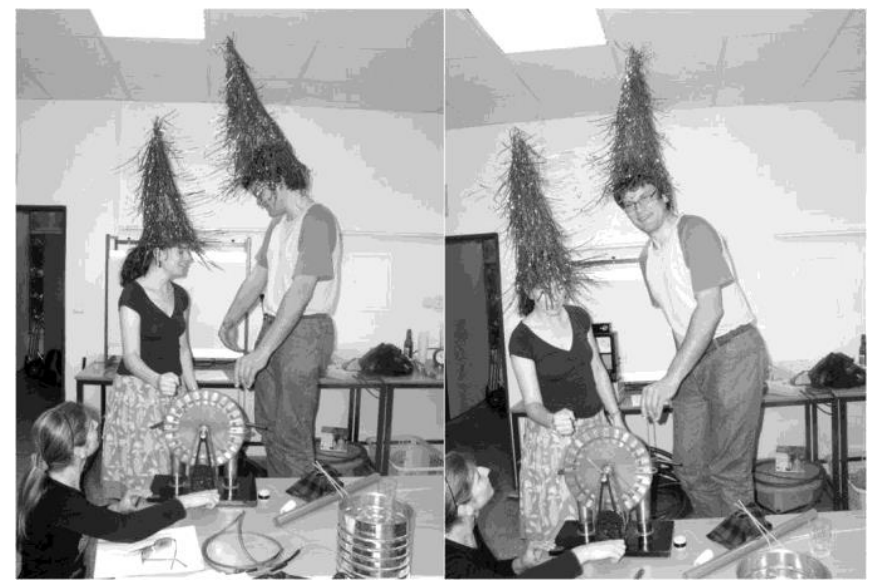

Figure 1. Playing with electrostatics 


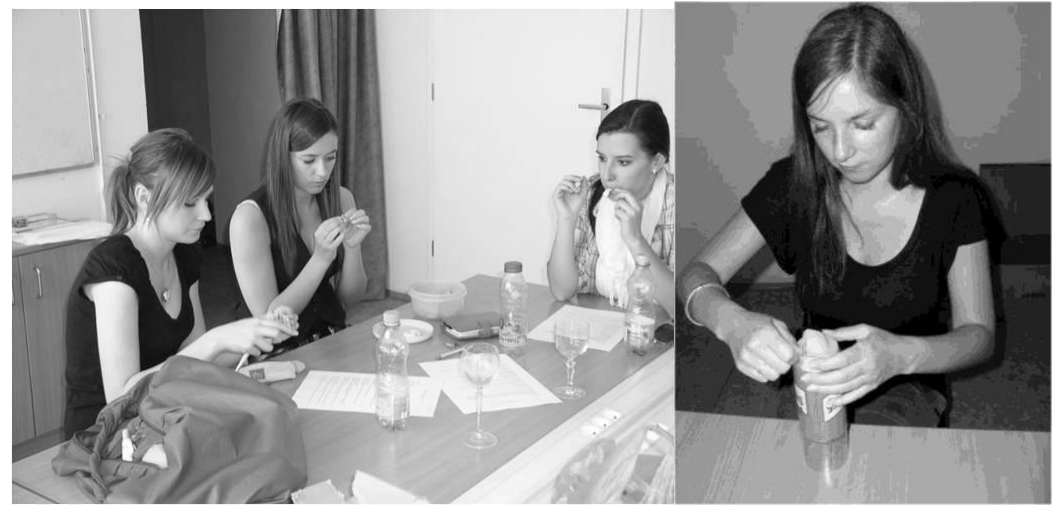

Figure 2. Acoustics - whistle and simple trumpet

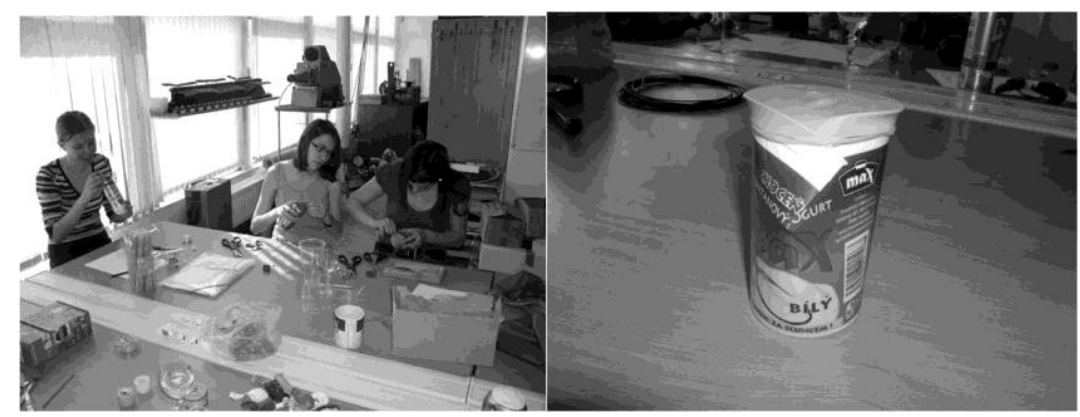

Figure 3. Acoustics - simple drums

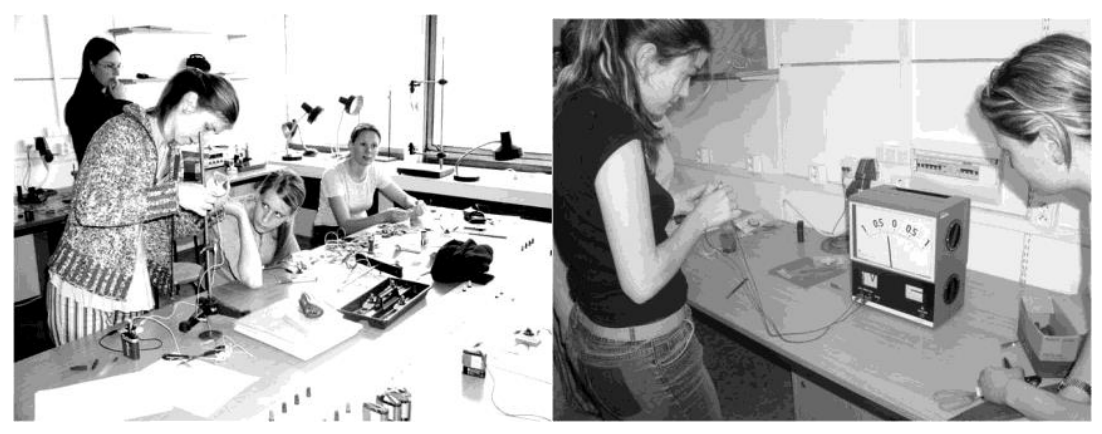

Figure 4. Electricity - take up with it (probably) for the first time

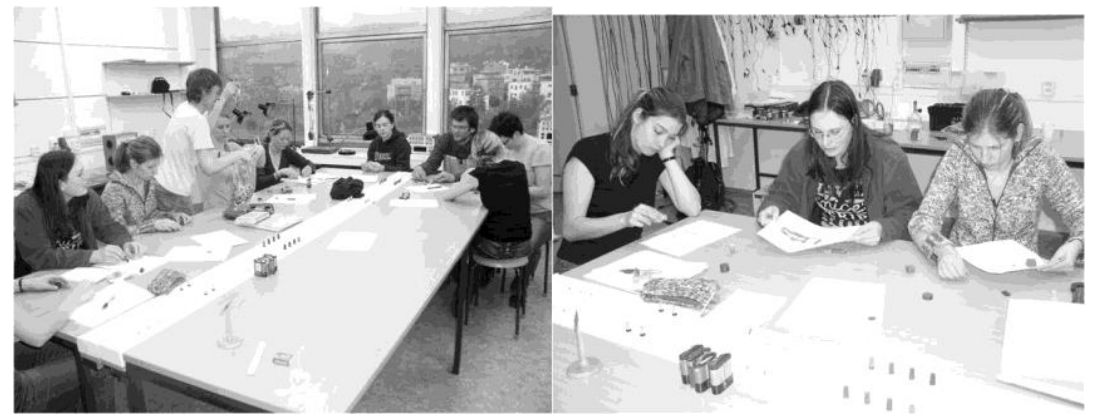

Figure 5. Magnetism - playing with magnets 


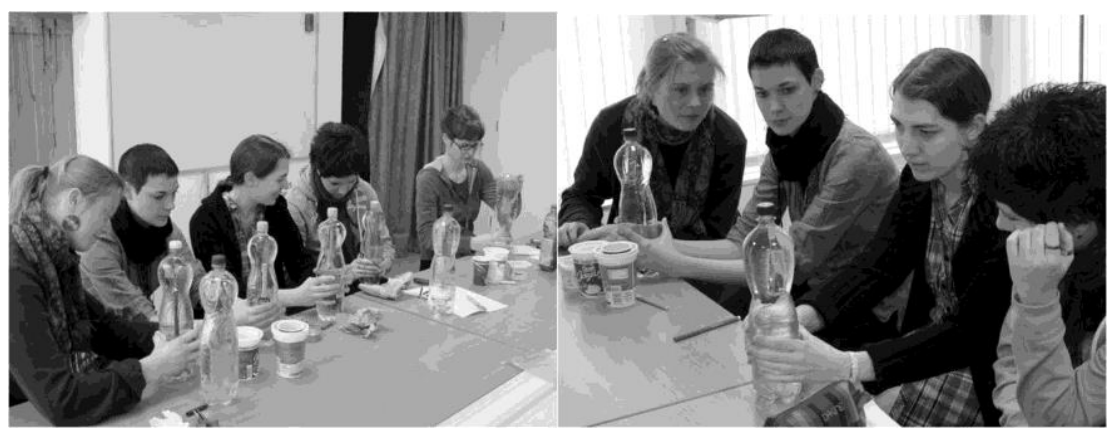

Figure 6. Cartesian diver

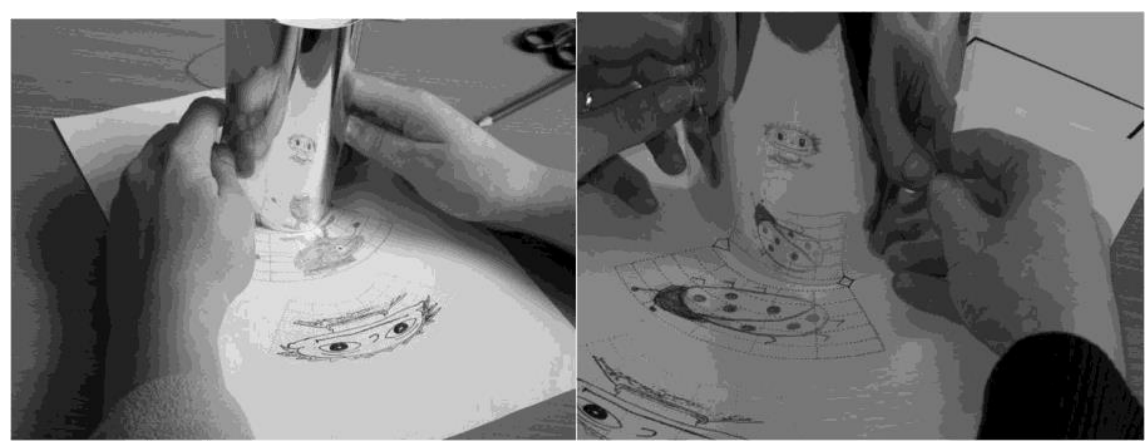

Figure 7. Wonderful optics

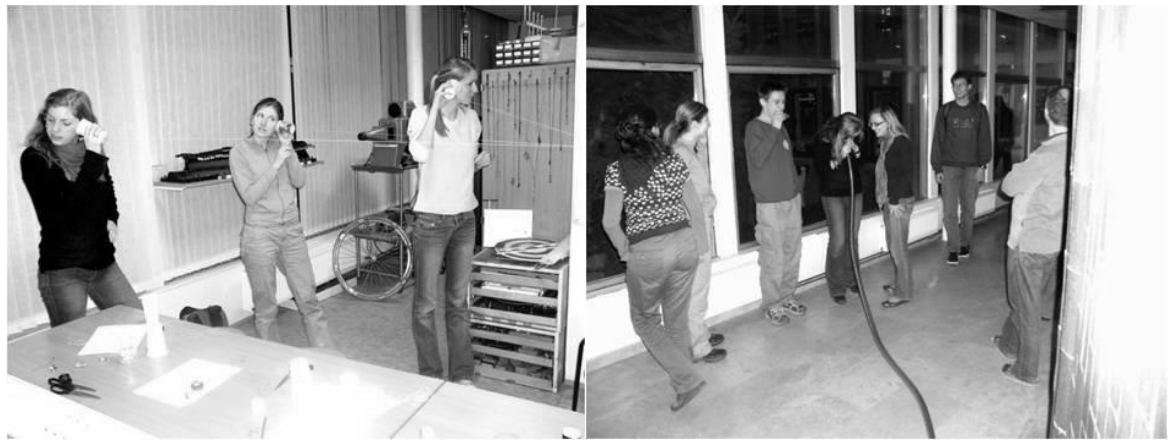

Figure 8. Various telephones

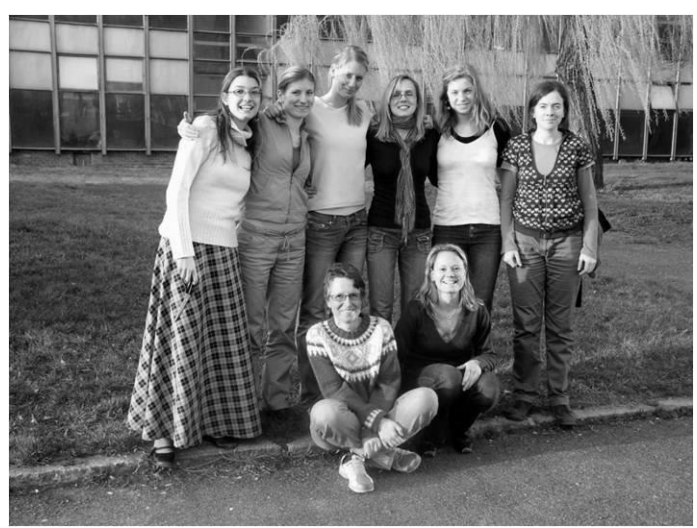

Figure 9. Group of the students with their lecturer 


\section{Conclusion}

Authors concluded that such a seminar brings new type of skills for future primary school teachers. They apply both, the skills and knowledge acquired there, in their school praxis after graduation from the university. The authors stay in contact with their former students to have appropriate feedback and use this information in improving the seminar.

\section{References}

Hejný M., Houfková, J., Jirotková, D., Laufková, V. Mandíková D. and Starý, K. (2013). Čtenářské, matematické a př́rodovědné úlohy pro proní stupeň základního vzdělávání. Praha, Česká školní inspekce.

Houfková, J., Mandikova, D., Drozd, Z.: Experiments in Science at Preschool/Kindergarten and Primary School. ICPE, Praha 2013. (in press)

Mandíková, D., Houfková, J., Drozd. Z.: Science teacher Training at the Department of Physics Education, MFF UK in Prague. In: Proceedings of the 10th International Conference on Hands-on-Science. Education for Science and through Science. Košice, Slovakia 2013, 215-219. 